\title{
economics-of-security.eu
}

Konstantinos Drakos and Cathérine Müller

\section{Terrorism Risk Concern in Europe}

June 2010

Economics of Security Working Paper 37

This publication is an output of EUSECON, a research project supported by the European Commission's Seventh Framework Programme.

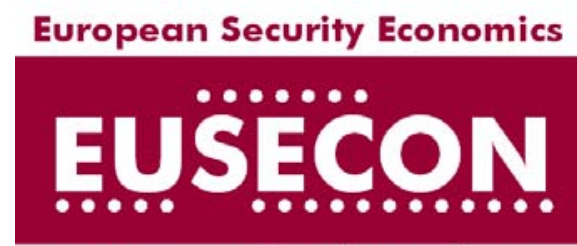

www.economics-of-security.eu

Economics of Security is an initiative managed by DIW Berlin 
Correct citation: Drakos, K. and Müller, C. (2010). "Terrorism Risk Concern in Europe". Economics of Security Working Paper 37, Berlin: Economics of Security.

First published in 2010

(c) Konstantinos Drakos and Cathérine Müller 2010

ISSN: 1868-0488

For further information, please contact:

Economics of Security, c/o Department of International Economics, German Institute for Economic Research (DIW Berlin), Mohrenstr. 58, 10117 Berlin, Germany.

Tel: +49 (0)30 $89789-277$

Email: eusecon@diw.de

Website: www.economics-of-security.eu 


\title{
Terrorism risk concern in Europe
}

\author{
Konstantinos Drakos ${ }^{* \dagger}$ \\ Department of Accounting and Finance \\ Athens University of Economics and \\ Business
}

\author{
Cathérine Müller \\ Department of International \\ Economics DIW Berlin, \\ Humboldt-University Berlin
}

\begin{abstract}
We explore whether differences of terrorism risk perception across all European countries reflect their underlying differences in terrorism risk, which we decompose into a long term and innovation component. We employ longitudinal country-level data on terrorism risk concern and our modeling approach is motivated by the Bayesian framework. We conclude that the observed risk perception variation is significantly explained by the long term terrorism countries face, while the cyclical part of terrorism activity does not affect risk perception.
\end{abstract}

\footnotetext{
*Corresponding author, kdrakos@aueb.gr, Address: 76 Patission Street, 10434, Athens, Greece.

${ }^{\dagger}$ The authors acknowledge financial support by the European Commission's $7^{\text {th }}$ Framework Programme ("A New Agenda for European Security Economics"). We would like to thank participants at the meeting of the Network for the Economic Analysis of Terrorism $\left(4^{\text {th }}\right.$ NEAT, Brussels, 2009) for their useful comments and suggestions.
} 


\section{Introduction}

We conduct the first longitudinal analysis on a pan-European level, investigating whether differences in terrorism risk are reflected on terrorism perception, motivated by the Bayesian framework (Viscusi and O'Connor 1984; Viscusi 1985; Viscusi et al. 1987; Rogers 1997). Pinning down the drivers of terrorism concern is important since it is known to affect various economic and non-economic aspects of behavior (Elster 1998; Schuster et al. 2001; Becker and Rubinstein 2004; Berrebi and Klor 2006; Frey et al. 2007).

\section{Data}

Data on terrorism concern for 2003-2008 (broken down to six month intervals Spring-Autumn) were obtained from the Eurobarometer (ZA: 3904, 3938, 4056, 4229, 4411, 4414, 4506, 4526, $4530,4565,4744)$ which is a harmonized survey of representative samples for Austria, Belgium, Bulgaria, Croatia, Cyprus, Czech Republic, Denmark, Estonia, Finland, France, Germany, Greece, Hungary, Ireland, Italy, Latvia, Lithuania, Luxemburg, Malta, Netherlands, Poland, Portugal, Romania, Slovakia, Slovenia, Spain, Sweden, Turkey, Great Britain and Northern Ireland. We use responses from the question:

"What do you think are the two most important issues facing (OUR COUNTRY) at the moment?"

Terrorism risk concern $\operatorname{trc}_{i, t}$ is calculated as the proportion of respondents that mentioned terrorism in the above question:

$$
\left(\operatorname{trc}_{i, t}\right)=\left(\frac{n_{i, t}}{N_{i, t}}\right)
$$


Where $(i)$ denotes country, $(t)$ time period, $n$ number of respondents mentioning terrorism, and $N$ the total number of survey participants.

We proxy terrorism risk by the following metric (Eckstein and Tsiddon 2004):

$$
\text { terrindex }_{i, t}=\log \left[\left(1+\text { deathrate }_{i, t}+\text { woundedrate }_{i, t}+\text { attackrate }_{i, t}\right)\right]
$$

Where:

attackrate $_{i, t}=\left(\frac{\text { count of terrorist attacks }}{100 \text { thousand inhabitants }}\right)_{i, t}$, deathrate $_{i, t}=\left(\frac{\text { count of fatal casualties }}{100 \text { thousand inhabitants }}\right)_{i, t}$ and woundedrate $_{i, t}=\left(\frac{\text { count of wounded }}{100 \text { thousand inhabitants }}\right)_{i, t}$.

This metric takes into account, not only the count of attacks, but also the severity of attacks. Data for the period 1994-2007 on terrorist events are obtained from the Global Terrorism Database (http://www.start.umd.edu/start/). Data on population were obtained from Eurostat.

\section{Modeling terrorism risk concern}

The Bayesian framework is our departure point where risk perception is a weighted average of the reference risk $\operatorname{trc}_{i, t}^{p}$, based on prior beliefs (ex ante perceived risk), and the arrival of new information $r_{i, t}^{s}$, corresponding to the sample risk inferred from the information (Viscusi and O'Connor 1984; Viscusi 1985, 1989; Smith and Michaels 1987; Smith and Johnson 1988; Loewenstein and Mather 1990; Smith et al. 1990; Evans and Viscusi 1991; Liu et al. 1998; Viscusi and Evans 1998; Smith et al. 2001):

$$
\operatorname{trc}_{i, t}=w_{1} \operatorname{trc}_{i, t}^{p}+w_{2} r_{i, t}^{s}
$$

Where $w_{1}, w_{2}$ are positive constants. 
In equation (3) one has to deal with the latent nature of the prior concern and the measurement of sample risk. To this end we assume that the public's prior terrorism concerns reflect a fundamental characteristic, and are shaped by the country's overall past experience with terrorism. Hence the first building block is that priors are a function of a country's long term history of terrorism risk $l t r_{i, t}$ :

$$
\operatorname{trc}_{i, t}^{p}=\beta \operatorname{ltr}_{i, t}
$$

Where $\beta>0$.

The sample risk is derived as the difference between current terrorism risk and long-term terrorism risk:

$$
r_{i, t}^{s}=\text { terrindex }_{i, t}-l t r_{i, t}
$$

Hence:

$$
\operatorname{trc}_{i, t}=w_{1} \beta \quad \text { ltr }_{i, t}+w_{2} \text { terrindex }_{i, t}-\text { ltr }_{i, t}
$$

Now equation (6) is operational provided that long-term terrorism risk and innovations of terrorism risk are available. We derive these quantities by employing a standard time series decomposition of terrindex $_{i, t}$, into a long-run trend $\tau_{i, t}$ and a cyclical component $c_{i, t}$, in an additive manner (see Harvey 1985; Clark 1987):

$$
\text { terrindex }_{i, t}=\tau_{i, t}+c_{i, t}
$$

We decompose the terrorism index employing 3 alternative smoothing specifications: moving averages (using windows of 1.5 or 2.5 years) or exponential smoothing, using a nonlinear optimizer to choose the smoothing parameter $\alpha$ which minimizes the sum of squared residuals. Thus, the trend component $\tau_{i, t}$ for each country is: 


$$
\begin{aligned}
\tau_{i, t}^{m a 3} & =\frac{\text { terrindex }_{i, t-2}+\text { terrindex }_{i, t-1}+\text { terrindex }_{i, t}}{3}, \\
\tau_{i, t}^{m a 5} & =\frac{\text { terrindex }_{i, t-4}+\text { terrindex }_{i, t-3}+\text { terrindex }_{i, t-2}+\text { terrindex }_{i, t-1}+\text { terrindex }_{i, t}}{5}, \text { and } \\
\tau_{i, t}^{\exp } & =\alpha^{*} \text { terrindex }_{i, t-1}+1-\alpha * \text { terrindex }_{i, t-2} .
\end{aligned}
$$

The estimation of the long term terrorism risk $\tau_{i, t}$ permits us to compute the cyclical component $c_{i, t}$, as the deviation of the current terrorism risk from the trend. Thus we explore the Bayesian property of terrorism concern by testing whether prior beliefs and new information have a positive and significant impact $(\delta \mathrm{s}>0)$ :

$$
\operatorname{trc}_{i, t}=\delta_{0}+\delta_{1} \tau_{i, t-1}^{j}+\delta_{2} c_{i, t-1}^{j}+\varepsilon_{i, t}
$$

Where the superscript $j$ denotes each alternative smoothing method and $\varepsilon_{i, t}$ is a random disturbance. The $\delta^{\prime} s$ are parameters estimated by the following alternative techniques: (i) pooled OLS with cluster-robust standard errors, (ii) Fixed-Effects, and (iii) Random-Effects. Also note that the trend and cycle variables are included in the model with a one period lag to ensure that the specification matches agents' available information set at the time of forming their terrorism risk concern.

\section{Empirical results}

Table 1 presents the empirical results from projecting risk concern on the long-term terrorism risk and its cyclical component, with cluster-robust standard errors. In addition, we conduct a battery of diagnostic tests for the sphericity of the error term $\varepsilon_{i, t}$, with special reference to two types of no-autocorrelation violations. In particular, we explore the possibility that the error 
terms exhibit time series autocorrelation: $\operatorname{Cov} \varepsilon_{i, t}, \varepsilon_{i, t-1} \neq 0 \forall i$. The second considers the possibility for cross-sectional dependence: $\operatorname{Cov} \varepsilon_{i, t}, \varepsilon_{j, t} \neq 0 \quad \forall i \neq j$. This type of error dependence would be relevant in the case where terrorism risk concern across European countries was subject to cross-country correlated shocks. Testing for these two types of correlation, we find significant cross-sectional error dependence (using the Pesaran's CD test, Pesaran 2004), but no serial correlation (Wooldridge 2002).

\section{-----Table 1-----}

Then we re-estimate model parameters with robust standard errors, accounting for error structures with cross-sectional correlation, applying the Driscoll and Kraay (1998) algorithm. Table 2 reports the relevant estimation results. As a further robustness check we also provide results including time dummies. Controlling for cross-sectional dependence yields qualitatively similar results as the models assuming spherical errors. Irrespectively of the smoothing method, concerns about terrorism are at best marginally affected by the cyclical component. The main driver through all specifications is the trend component of terrorism risk. This implies that terrorism concern cannot be tackled on a short term basis. Rather, people observe the evolution of the terrorism risk and evaluate its long-term trend.

\section{-----Table 2-----}

\section{Conclusions}

We decomposed country terrorism risk into long and short run components, and investigated whether they account for risk perception across European countries. We conclude that risk perception variation is only explained by the long term terrorism countries face. In contrast, the cyclical part of terrorism activity does not affect risk perception. Future research could be 
directed towards a micro level analysis accounting for respondents' heterogeneity captured by their personal characteristics. Moreover, one could also explore location and timing effects of terrorist incidents as determinants of terrorism risk concern. 


\section{References}

Becker, G. and Rubinstein, Y. (2004): "Fear and the response to terrorism: an economic analysis," University of Chicago, online http://econ.tau.ac.il/papers/faculty/beckerrubinstein_may11.pdf.

Berrebi, C. and Klor, E. F. (2006): "On Terrorism and Electoral Outcomes: Theory and Evidence from the Israeli-Palestinian Conflict," Journal of Conflict Resolution 50(6), 899-925.

Clark, P. K. (1987): “The Cyclical Component of U.S. Economic Activity,” Quarterly Journal of Economics 102, 797-814.

Driscoll, J. C. and Kraay, A. (1998): “Consistent Covariance Matrix Estimation with Spatially Dependent Panel Data," Review of Economics and Statistics 80, 549-560.

Eckstein, Z. and Tsiddon, D. (2004): "Macroeconomic consequences of terror: Theory and the case of Israel,” Journal of Monetary Economics 51(5), 971-1002.

Elster, J. (1998): "Emotions and economic theory," Journal of Economic Literature 36, 47-74.

Evans, W. N. and Viscusi, W. K. (1991): "Estimation of State-Dependent Utility Functions Using Survey Data," Review of Economics and Statistics 73(1), pages 94-104.

Frey, B. S., Luechinger, S. and Stutzer, A. (2007): “Calculating Tragedy: Assessing The Costs Of Terrorism,” Journal of Economic Surveys 21(2) 1-24.

Harvey, A. C. (1985): "Trends and Cycles in Macroeconomic Time Series," Journal of Business and Economic Statistics 3, 216-227.

Loewenstein, G., and Mather, J. (1990): "Dynamic processes in Risk Perception," Journal of Risk and Uncertainty 3(2), 155-175.

Pesaran, M. H. (2004): "General diagnostic tests for cross section dependence in panels," Cambridge Working Papers in Economics 0435.

Rogers, G. O. (1997): “The Dynamics of Risk Perception: How Does Perceived Risk Respond to Risk Events," Risk Analysis 17(6), 745 - 757.

Liu, S., Huang J. C. and Brown G. L. (1998): "Information and Risk Perception: A Dynamic Adjustment Process," Risk Analysis 18(6), 689-699.

Schuster, M., Stein, B., Jaycox, L., Collins, R., Marshall, G., Elliot, M., Zhou, A., Kanouse, D., Morrison, J. and Berry, S. (2001): "A national survey of stress reactions after the September 11, 2001, terrorist attacks," New England Journal of Medicine 345(20), 1507-1512. 
Smith, V. K., and Johnson, F. R. (1988): "How Do Risk Perceptions Respond to Information: The Case of Radon," Review of Economics and Statistics 70(1), 1-8.

Smith, V. K., Taylor, D. H. Jr., Sloan, F. A., Johnson, F. R. and Desvousges, W. H. (2001): “Do Smokers Respond to Health Shocks?" Review of Economics and Statistics 83(4), 675-687.

Smith, V. K., and Michaels, R. G. (1987): "How Did Households Interpret Chernobyl? A Bayesian Analysis of Risk Perception," Economics Letters 23(4), 359-364.

Smith, V. K., Desvousges, W. H., Johnson, F. R., and Fisher, A. (1990): "Can Public Information Programs Affect Risk Perceptions?" Journal of Policy Analysis and Management 9, 41-59.

Viscusi, W. K. (1989): "Prospective Reference Theory: Toward an Explanation of the Paradoxes," Journal of Risk and Uncertainty 2(3), 235-263.

Viscusi, W. K. (1985): “A Bayesian Perspective on Biases in Risk Perceptions," Economics Letters 17(1), 59-62.

Viscusi, W. K., and Evans, N. E. (1998): "Estimation of Revealed Probabilities and Utility Functions for Product Safety Decisions," Review of Economics and Statistics 80(1), 28-33.

Viscusi, W. K., and O'Connor, C. J. (1984): “Adaptive Responses to Chemical Labeling: Are Workers Bayesian Decision Makers?” American Economic Review 74(5), 942-956.

Viscusi, W. K., Magat, W. A., and Huber, J. (1987): "An Investigation of the Rationality of Consumer Valuations of Multiple Health Risks," RAND Journal of Economics 18(4), 465479.

Wooldridge, J. M. (2002): "Econometric Analysis of Cross Section and Panel Data" Cambridge, MA: The MIT Press. 


\section{Tables}

\begin{tabular}{|c|c|c|c|c|c|c|c|c|c|}
\hline $\begin{array}{c}\text { Estimation } \\
\text { method }\end{array}$ & $\begin{array}{r}\text { Pooled O } \\
\mathrm{s}\end{array}$ & $\begin{array}{l}\text { S with clu } \\
\text { ndard err }\end{array}$ & $\begin{array}{l}\text { er-robust } \\
\text { s }\end{array}$ & & ixed Effe & & & ndom Eff & \\
\hline Regressor & $\begin{array}{c}\text { MA3 } \\
\text { Filter }^{(b)}\end{array}$ & $\begin{array}{l}\text { MA5 } \\
\text { Filter } \\
\end{array}$ & $\begin{array}{l}\text { EXP. } \\
\text { Filter }\end{array}$ & $\begin{array}{l}\text { MA3 } \\
\text { Filter }\end{array}$ & $\begin{array}{l}\text { MA5 } \\
\text { Filter }\end{array}$ & $\begin{array}{l}\text { EXP. } \\
\text { Filter }\end{array}$ & $\begin{array}{l}\text { MA3 } \\
\text { Filter }\end{array}$ & $\begin{array}{l}\text { MA5 } \\
\text { Filter }\end{array}$ & $\begin{array}{c}\text { EXP. } \\
\text { Filter }\end{array}$ \\
\hline trend & $\begin{array}{l}0.503^{\text {**** }} \\
(0.141)\end{array}$ & $\begin{array}{l}0.510^{* *} \\
(0.187)\end{array}$ & $\begin{array}{l}0.410^{\text {**** }} \\
(0.137)\end{array}$ & $\begin{array}{l}0.131^{* * *} \\
(0.056)\end{array}$ & $\begin{array}{c}0.126 \\
(0.099)\end{array}$ & $\begin{array}{l}0.426^{* * * *} \\
(0.118)\end{array}$ & $\begin{array}{l}0.172^{*} \\
(0.093)\end{array}$ & $\begin{array}{l}0.194^{*} \\
(0.101)\end{array}$ & $\begin{array}{l}0.419^{\text {***** }} \\
(0.073)\end{array}$ \\
\hline cycle & $\begin{array}{l}-0.016 \\
(0.045) \\
\end{array}$ & $\begin{array}{c}0.013 \\
(0.045) \\
\end{array}$ & $\begin{array}{c}0.135 \\
(0.084) \\
\end{array}$ & $\begin{array}{l}-0.005 \\
(0.055) \\
\end{array}$ & $\begin{array}{c}0.011 \\
(0.054) \\
\end{array}$ & $\begin{array}{c}0.044 \\
(0.031) \\
\end{array}$ & $\begin{array}{l}-0.006 \\
(0.045) \\
\end{array}$ & $\begin{array}{c}0.011 \\
(0.046) \\
\end{array}$ & $\begin{array}{c}0.050 \\
(0.040) \\
\end{array}$ \\
\hline Intercept & $\begin{array}{c}0.070^{\text {***** }} \\
(0.015)\end{array}$ & $\begin{array}{l}0.068^{\text {***** }} \\
(0.014)\end{array}$ & $\begin{array}{l}0.071^{\text {***** }} \\
(0.017)\end{array}$ & $\begin{array}{l}0.086^{\text {***** }} \\
(0.002)\end{array}$ & $\begin{array}{l}0.086^{\text {**** }} \\
(0.005)\end{array}$ & 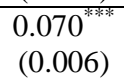 & $\begin{array}{l}0.080^{\text {***** }} \\
(0.017)\end{array}$ & $\begin{array}{l}0.079^{\text {***** }} \\
(0.016)\end{array}$ & $\begin{array}{c}0.067^{\text {*3*6\% }} \\
(0.011)\end{array}$ \\
\hline & \multicolumn{9}{|c|}{ Diagnostics } \\
\hline $\begin{array}{c}\text { Serial } \\
\text { correlation test } \\
\text { (c) }\end{array}$ & 0.885 & 0.821 & 0.376 & 0.885 & 0.821 & 0.376 & 0.885 & 0.821 & 0.376 \\
\hline $\begin{array}{c}\text { Cross-sectional } \\
\text { independence } \\
\text { test }^{(\mathrm{d})}\end{array}$ & 0.000 & 0.000 & 0.000 & 0.000 & 0.000 & 0.000 & 0.000 & 0.000 & 0.000 \\
\hline $\begin{array}{c}\text { R-squared } \\
\text { (within) }\end{array}$ & - & - & - & 0.031 & 0.018 & 0.117 & 0.031 & 0.018 & 0.117 \\
\hline $\begin{array}{c}\text { R-squared } \\
\text { (between) }\end{array}$ & - & - & - & 0.403 & 0.378 & 0.199 & 0.403 & 0.378 & 0.201 \\
\hline $\begin{array}{c}\text { R-squared } \\
\text { (overall) }\end{array}$ & 0.275 & 0.284 & 0.200 & 0.275 & 0.283 & 0.184 & 0.275 & 0.284 & 0.186 \\
\hline Observations & 288 & 288 & 288 & 288 & 288 & 288 & 288 & 288 & 288 \\
\hline $\begin{array}{l}\text { Overall } \\
\text { significance }(p- \\
\text { value) }\end{array}$ & 0.000 & 0.000 & 0.000 & 0.003 & 0.100 & 0.001 & 0.173 & 0.159 & 0.000 \\
\hline \multicolumn{10}{|c|}{$\begin{array}{l}\text { Notes: (a) } * * *, * * * \text { denote significance at the } 10,5 \text { and } 1 \text { percent level respectively, (b) MA3, MA5 and EXP Filter stand for the } \\
\text { moving average smoother with } 3 \text { and } 5 \text { observations, and the exponential smoother respectively, (c) Wooldridge (2002), (d) Pesarar } \\
(2004) \text {. }\end{array}$} \\
\hline
\end{tabular}




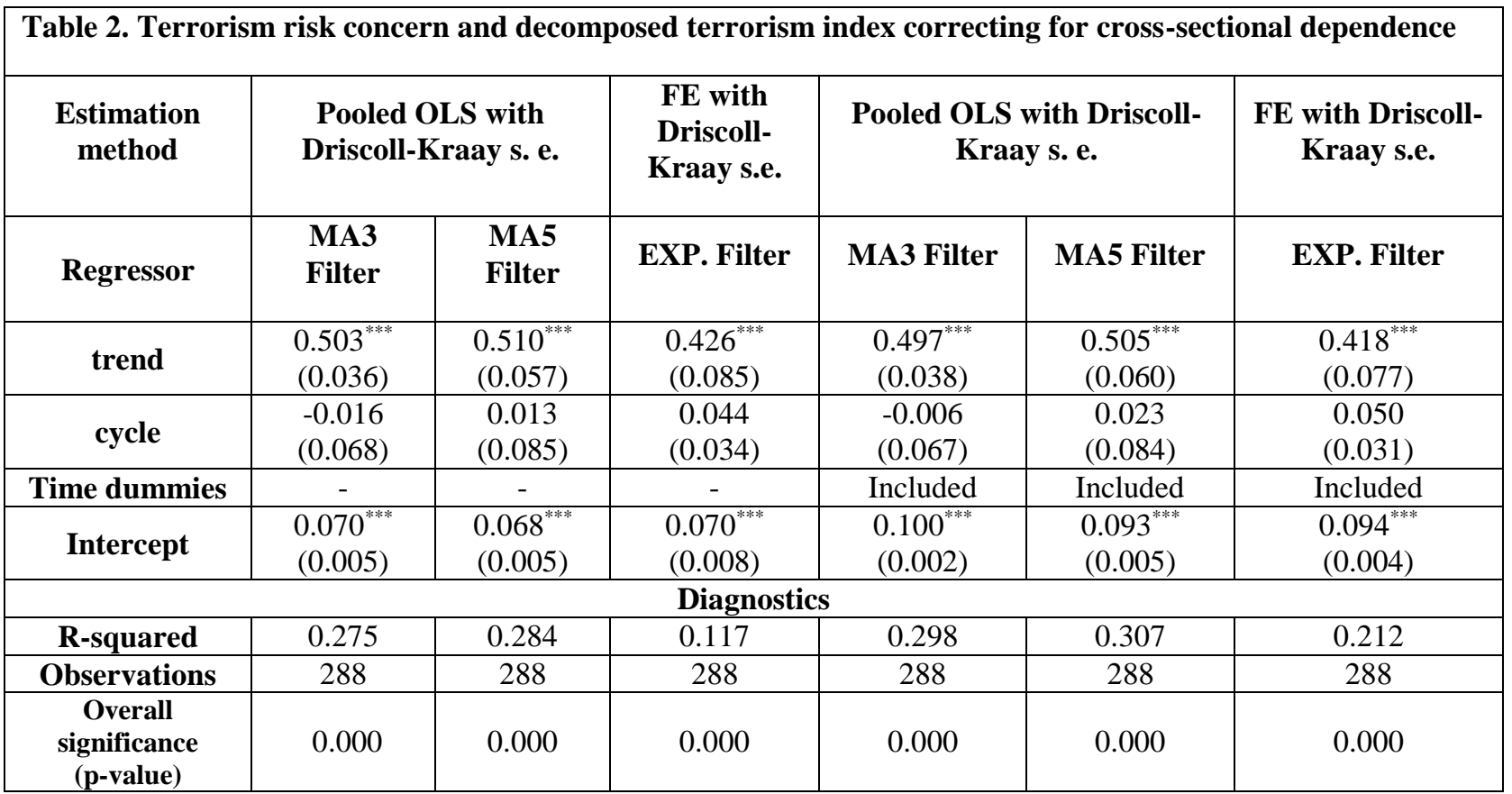

